\title{
Determinants Of Students' Performance In Intermediate Accounting
}

Elaine Waples, (E-mail: waples@calumet.purdue.edu), Purdue University Calumet Musa Darayseh, (E-mail: mdarayseh@aus.edu), American University of Sharjah, UAE

\begin{abstract}
The purpose of this study is to investigate factors that may influence student performance in the first intermediate accounting class. Regression analysis is used to examine the significance of four independent variables: cumulative grade point average prior to enrolling in intermediate accounting, grade in the introductory financial accounting class, grade in the introductory managerial accounting class, and score on a diagnostic assessment used to measure general financial accounting knowledge. Based on the results, several recommendations are offered to improve student performance.
\end{abstract}

\section{INTRODUCTION}

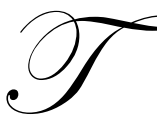

he first intermediate accounting course is required for accounting and finance majors at many American universities. Moreover, at some universities general management majors also take this course. Many students face considerable difficulty in successfully completing intermediate accounting. The amount of material typically covered is substantial and the course requires of the student a significant increase in motivation, analytical ability, and academic effort over the usual principles or introductory financial accounting class. For some students, there is a gap of more than a year between the time they take beginning financial accounting and the time they begin the intermediate accounting sequence. Finally, at some universities, the prerequisite requirement may be set so low that marginal students who barely earned a $\mathrm{C}$ in the introductory accounting classes are allowed to enroll directly in intermediate accounting. Factors that are beyond the control of students but may affect their performance include institutional issues such as large class size and heavy teaching load for the instructor. There may also be limited availability of supplemental instruction or tutoring assistance. All of these factors may adversely affect the probability of student success in intermediate accounting.

The purpose of this study is to investigate some of the factors that may influence student performance in the first intermediate accounting class. Identifying the factors that are positively related to performance should enhance faculty understanding of the problems related to student failure in intermediate accounting, whether that failure means dropping out of the class or receiving a less than passing grade. In addition, identifying these factors could result in accounting departments developing more effective curriculum, enrollment policies, and prerequisites for the first intermediate course.

Regression will be used to test the relationship of several variables to performance in the first intermediate accounting class. The paper is organized as follows. We begin with a brief review of the literature, next we describe the setting for the study and the collection of data, then we present the results of the regression, and finally, we discuss the implications of the results and offer recommendations which might increase the probability of success in intermediate accounting.

\section{LITERATURE REVIEW}

Previous research indicates that overall grade-point average (GPA) and accounting (principles) grade-point average are factors influencing students' performance in Intermediate Accounting. Hicks and Richardson (1984) focused on three possibilities for predicting success: (1) score on diagnostic test of knowledge at the beginning of the intermediate sequence; (2) overall grade-point average (GPA); and (3) accounting (principles) grade-point average. The results indicated that an entry examination covering the basic accounting cycle was a significant predictor of 
student performance. Both measures of GPA were also significant. McCormick and Montgomery (1974) examined AICPA level I and II tests, Graduate Record Examination (GRE), and Cooperative SCAT tests for evaluating students transferring to Florida Atlantic University. They found the test scores useful for evaluating knowledge and predicting intermediate accounting grades. Delaney, et al. (1979) examined the correlation between performance on an admission test for intermediate accounting and performance in the course at Northern Illinois University. They found significant correlations between test scores and course grade and between managerial accounting grade and intermediate grade.

The present study examines the relationship of specific accounting achievements in the recent past to performance in Intermediate Accounting. Grades from the first two accounting courses and a Diagnostic Assessment testing introductory financial accounting knowledge are included in the analysis. Also included is an indicator of overall academic ability — grade point average. Since earlier studies have shown a difference in results for different student bodies, it appears appropriate that more data be gathered on this topic.

\section{DESCRIPTION OF THE STUDY}

Purdue University Calumet, located in Hammond, Indiana, is a regional campus with approximately 9,400 students. Historically, it has been strictly a commuter campus with student housing only becoming available in August of 2005. Many of the students work and attend college part-time. The university and the School of Management, where the Accounting Department is housed, have had basically open admissions for many years. To enroll in the first intermediate class, students need only have grades of $\mathrm{C}$ or better (on a four-point scale) in Introductory Financial Accounting and Introductory Managerial Accounting. This two-course sequence is used instead of Accounting Principles I and II at Purdue Calumet. At the time of the study, there was no limit on the number of times a student could take the class, so withdrawals without receiving a grade are fairly common when students realize they are not going to succeed in the class. The dropout rate, a matter of great concern to the faculty, averages about $20 \%$ during a typical semester.

All students who completed Intermediate Accounting One during the first and second semesters of 2003/2004 and 2004/2005 at Purdue Calumet were the subjects of the study. The same instructor taught all classes during this time period and collected all the data. All students used the same textbook (Kieso and Weygandt) and were assigned identical homework problems from the text. There were 157 observations.

Variables were chosen based on previous research and the availability of data. Performance (grade) in Intermediate Accounting One was the dependent variable. The four independent variables were cumulative university grade point average (GPA) before taking Intermediate Accounting, grade in Introductory Financial Accounting, grade in Introductory Managerial Accounting, and score on a Diagnostic Assessment given during the first few weeks of class. The Diagnostic Assessment measured overall preparation in financial accounting at the introductory level. The data was analyzed using multiple regression on Excel. (The study was reviewed and accepted by the university's Institutional Research Board.)

\section{MODEL AND VARIABLES}

The following model has been created to investigate factors which may determine students' performance in Intermediate Accounting One. The model hypothesized that the performance in intermediate accounting depends on cumulative GPA at the university, score on Diagnostic Assessment, passing grade in Introductory Financial Accounting, and passing grade in Introductory Managerial Accounting. The regression model examined for Intermediate Accounting One is as follows:

GRADE $=b_{0}+b_{1}$ GPA $+b_{2}$ DIAG $+b_{3}$ FINGRD $+b_{4}$ MGRGRD

GRADE $=$ grade of student in Intermediate Accounting I

GPA $=$ grade point average at university before enrolling in Intermediate Accounting

DIAG $\quad=$ score on diagnostic assessment 
FINGRD $\quad=$ passing grade in Introductory Financial Accounting

MGRGRD $\quad=$ passing grade in Introductory Managerial Accounting

This model was estimated using Ordinary Least Squares (OLS) method.

\section{RESULTS}

Table 1 presents the descriptive statistics for the variables used in the regression model 2. It can be noted that the mean of the grades in Intermediate Accounting One is 2.516 on a four-point scale. This is considerably lower than the average cumulative GPA (3.037) recorded before students took Intermediate Accounting One. The mean grade in intermediate is also lower than the average grade in Introductory Financial Accounting (2.962) and the average grade in Introductory Managerial Accounting (2.809). These are not surprising findings, given the substantial increase in difficulty and workload of Intermediate Accounting over the introductory accounting sequence.

Table 1: Descriptive Statistics

\begin{tabular}{|l|c|c|}
\hline Variable & Mean & Std. Dev. \\
\hline GRADE & 2.516 & 0.805 \\
\hline GPA & 3.037 & 0.416 \\
\hline DIAG & 75.350 & 18.417 \\
\hline FINGRD & 2.962 & 0.759 \\
\hline MGRGRD & 2.809 & 0.818 \\
\hline
\end{tabular}

Correlation statistics are presented in Table 2. Of the independent variables, cumulative GPA and score on Diagnostic Assessment are the most highly correlated with the dependent variable, final grade in Intermediate Accounting One. However, GPA and Score on Diagnostic Assessment are not highly correlated with each other. The high correlation (0.722) between the other two independent variables, grade in Introductory Financial Accounting and grade in Introductory Managerial Accounting, suggests there may be a problem with multicollinearity in the regression model. The dependent variable is not highly correlated with grade in Introductory Financial Accounting or grade in Introductory Managerial Accounting, while GPA is highly correlated with those two independent variables. The correlations suggest that grade in Introductory Financial Accounting and grade in Introductory Managerial will not provide any additional predictive value to the model, beyond that provided by GPA.

Table 2: Correlation Statistics

\begin{tabular}{|c|c|c|c|c|c|}
\hline & GRADE & GPA & DIAG & FIN GRD & MGR GRD \\
\hline GRADE & 1 & & & & \\
\hline GPA & 0.727 & 1 & & & \\
\hline DIAG & 0.871 & 0.459 & 1 & & \\
\hline FINGRD & 0.568 & 0.680 & 0.405 & 1 & \\
\hline MGRGRD & 0.550 & 0.697 & 0.366 & 0.722 & 1 \\
\hline
\end{tabular}

The regression results for the original model are reported in Table 3. The overall model is significant with an adjusted $R^{2}$ of 0.893 , but as the correlations suggested, the independent variables represented by grades in Introductory Financial Accounting and in Introductory Managerial Accounting were not significant. 
Table 3: Regression Model Results of the Original Model

\begin{tabular}{|c|c|c|c|}
\hline R Square & 0.895 & & \\
\hline Adjusted R Square & 0.893 & & \\
\hline F statistic & 325.4 & & \\
\hline \multirow[t]{2}{*}{ p-value } & $<0.001$ & & \\
\hline & $\mathrm{n}=157$ & & \\
\hline Variable & Coefficients & t Stat & p-value \\
\hline Intercept & -2.1339 & -12.95 & $<0.01$ \\
\hline GPA & 0.7679 & 9.81 & $<0.01$ \\
\hline DIAG & 0.0297 & 22.76 & $<0.01$ \\
\hline FINGRD & -0.0116 & 0.27 & 0.79 \\
\hline MGRGRD & -0.0164 & 0.40 & 0.69 \\
\hline
\end{tabular}

When the two independent variables, grade in Introductory Financial Accounting and grade in Introductory Managerial Accounting, are removed from the regression, there is virtually no change in the $\mathrm{R}^{2}$ of the model. Regression results for the final model are presented in Table 4. It appears that GPA serves as both a general indicator of academic ability and a proxy for achievement in the introductory accounting classes. The extremely strong relationship of the score on the diagnostic assessment and the final grade in intermediate accounting is also interesting and somewhat surprising. In this study, the diagnostic assessment is a much better predictor of performance in intermediate accounting than the grade received in the introductory financial accounting class. This may be specific to the university or this group of students. At Purdue Calumet, there are several different instructors teaching introductory financial accounting. Some instructors are much more rigorous in their requirements than others. Another issue is the timing of the diagnostic assessment. It is not an entrance requirement; it is given in the first few weeks of the semester. By that time, some of the less qualified students may have decided to drop the class. In addition, the intermediate accounting instructor prepared the questions for the diagnostic assessment which could introduce some bias. The use of a generally recognized financial accounting assessment or diagnostic exam might widen the applicability of the results.

Table 4 Regression Model Results of the Final Model

\begin{tabular}{|c|c|c|c|}
\hline R Square & 0.895 & & \\
\hline Adjusted R Square & .894 & & \\
\hline F statistic & 657.3 & & \\
\hline $\mathrm{p}$-value & $<0.001$ & & \\
\hline \multicolumn{4}{|l|}{$\mathrm{n}=157$} \\
\hline Variable & Coefficients & t Stat & p-value \\
\hline Intercept & -2.1668 & -13.90 & $<0.01$ \\
\hline GPA & 0.8028 & 14.12 & $<0.01$ \\
\hline DIAG & 0.0298 & 23.19 & $<0.01$ \\
\hline
\end{tabular}

\section{IMPLICATIONS AND RECOMMENDATIONS}

The results of this study show that proper foundation in basic financial accounting knowledge (measured by a diagnostic assessment) and overall level of academic ability (measured by cumulative GPA) are both important indicators of success in the first intermediate accounting class. For the accounting educator, there are several possible 
implications of these findings, although it is important to recall the setting for the study. Purdue Calumet has essentially open admissions and there is no required GPA to take Intermediate Accounting other than grades of $\mathrm{C}$ or better in Introductory Financial Accounting and in Introductory Managerial Accounting. For educators in similar university settings, we offer several recommendations.

A minimum grade point to enroll in intermediate accounting may improve the probability of success. Intermediate accounting is often the first upper level accounting class that students take and, at some universities, it has been used as the course that separates out the unqualified or unmotivated students who think they want to major in accounting. Setting a minimum GPA (for example, a 2.5 cumulative) to enroll in the course would underscore the difficulty of the material and perhaps motivate students to apply themselves immediately.

In the absence of an overall GPA requirement, a minimum required GPA for the two introductory accounting classes might serve the same purpose. Requiring at least a 2.5 (on a four point scale) GPA in the first two accounting classes would also highlight the fact that intermediate is a very large step up in difficulty from the first financial or principles course.

Using a diagnostic assessment to identify students at risk at the beginning of the semester may help improve student success if required remedial work is provided for students scoring below average. Without the proper foundation in financial accounting, students will play catch-up the whole semester in intermediate. Requiring students to make up their deficiencies immediately should enhance the learning environment for both students and instructors.

Supplemental instruction or in-class graduate aides or tutors may improve the potential for success of students who are motivated but simply lack the necessary study skills. Obviously, this type of extra help only benefits students who take advantage of it. Required tutoring for students who have marginal GPAs or demonstrate their lack of foundation by scoring below average on the diagnostic assessment may also improve student success.

Even at a university with open admissions and within an accounting department with low minimum requirements, student performance in Intermediate Accounting can be improved. When students without proper preparation are identified early in the semester through a diagnostic assessment, deficiencies can be overcome with required remedial support. Raising the intermediate entrance requirement only slightly could discourage marginal students who would be more successful in another major. In-class supplemental instruction would also benefit many students who are on the edge of succeeding. It is hoped that further research in this area will uncover other factors that determine student performance in intermediate accounting.

\section{REFERENCES}

1. Albrecht, W. Steve and Robert J. Sack, Accounting Education: Charting the Course through a Perilous Future (August 2000), American Accounting Association.

2. Delaney, P.R., D. E. Keys, C. L. Norton, and J. R. Simon, An Admission Test for Intermediate Accounting, The Accounting Review (January 1979), pp.155-162.

3. Dow, Kathy J., and Dorothy A. Feldmann, Current Approaches to Teaching Intermediate Accounting, Issues in Accounting Education (Spring 1997), pp. 61-75.

4. Hicks, W. Donald and Richardson M. Frederick, Predicting Early Success in Intermediate Accounting: The Influence of Entry Examination and GPA, Issues in Accounting Education (1984), pp. 61-64.

5. Ingram. R. W. and Peterson. R. J., An Evaluation of AICPA Test for Predicating the Performance of Accounting Majors, The Accounting Review (January 1987), pp. 215-223.

6. McCormick, R. R. and J. B. Montgomery, The Use of AICPA Tests in Evaluating Transfer Students at a University, Journal of Accountancy (August 1974), pp. 82-88. 


\section{NOTES}

